\title{
KORELASI KECEPATAN EFEKTIF MEMBACA DAN KEMAMPUAN MENYINTESIS BACAAN SISWA KELAS XI DI MADRASAH ALIYAH NEGERI 1 CIREBON
}

\author{
Reza Muamar Zaki, Itaristanti, Tato Nuryanto \\ IAIN Syekh Nurjati Cirebon \\ Email: zakikipaw@gmail.com, salsabilamashel@gmail.com, \\ tatonuryanto@gmail.com
}

\begin{abstract}
Abstrak: Rendahnya minat baca terutama pada pelajar yang dibuktikan oleh riset yang dilakukan PISA, UNESCO, dan CCSU. Penelitian ini bertujuan untuk mendeskripsikan kecepatan membaca siswa kelas XI di MAN 1 Kota Cirebon, untuk mendeskripsikan hasil menyintesis bacaan siswa kelas XI di MAN 1 Kota Cirebon, untuk mendeskripsikan korelasi antara kecepatan efektif membaca dan hasil sintesis bacaan pada siswa kelas XI di MAN 1 Kota Cirebon. Penelitian ini merupakan penelitian kuantitatif dengan kategori penelitian studi korelasional. Teknik analisis yang digunakan yaitu teknik analisis korelasi untuk mengetahui hubungan antarvariabel. Berdasarkan hasil analisis dengan SPSS 25 kecepatan efektif membaca pada siswa kelas XI di MAN 1 Cirebon pada kategori tinggi sebanyak 12 responden (35,29\%), kategori sedang sebanyak 15 reponden $(44,12 \%)$, kategori rendah sebanyak 7 responden (20,59\%). Kemampuan menyintesis bacaan siswa kelas XI di MAN 1 Cirebon frekuensi berada pada kategori tinggi sebanyak 2 reponden $(5,88 \%)$, pada kategori sedang sebanyak 22 responden $(64,71 \%)$, pada kategori rendah sebanyak 7 responden $(29,41 \%)$. Terdapat korelasi antara kecepatan efektif membaca dan hasil menyintesis bacaan, namun tidak signifikan karena thitung senilai 0,076 lebih kecil dari tabel senilai 2,042.
\end{abstract}

Kata Kunci: kecepatan membaca, kemampuan menyintesis, korelasi, siswa MAN

\section{EFFECTIVE READING SPEED CORRELATION WITH READING SYNTHESIS ABILITY IN CLASS XI STUDENTS IN MAN 1 CIREBON}

\begin{abstract}
The low interest in reading, especially among students, is evidenced by research conducted by PISA, UNESCO, and CCSU. This study aims to describe the reading speed of class $X I$ students at MAN 1 Cirebon City, to describe the results of synthesizing the reading of class XI students at MAN 1 Cirebon City, to describe the correlation between the effective speed of reading and the results of reading synthesis in class XI students in MAN 1 Cirebon City. This research is a quantitative research with the category of correlational study research. The analysis technique used is the correlation analysis technique to determine the relationship between variables. Based on the results of the analysis with SPSS 25, the effective speed of reading in class XI students at MAN 1 Cirebon in the high category is 12 respondents (35.29\%), the moderate category is 15 respondents $(44,12 \%)$, the low category was 7 respondents (20.59\%). The ability to synthesize the reading of class XI students at MAN 1 Cirebon, the frequency was in the high category as many as 2 respondents (5.88\%), in the medium category as many as 22 respondents (64.71\%), in the low category was 7 respondents (29, 41\%). There is
\end{abstract}

BASASTRA Jurnal Bahasa, Sastra, dan Pengajarannya

Volume 9 Nomor 1, April 2021, P-ISSN 2302-6405, E-ISSN 2714-9765 
a correlation between the effective speed of reading and the results of synthesizing the reading, but it is not significant because the $t_{\text {count }}$ of 0.076 is smaller than the $t_{\text {table }}$ of 2.042 .

Keywords: speed of reading, synthesizing reading, corelations, MAN students

PENDAHULUAN

Kegiatan membaca adalah aktivitas berbahasa yang bersifat aktif reseptif (Pamuji, 2017: 70). Menurut Dalman (2013: 29) kriteria pembaca cepat yang baik adalah pembaca yang dapat membaca dengan cepat dan tahu maksud yang dibacanya. Selaras dengan Tampubolon (2015: 7) menjelaskan bahwa kecepatan membaca tidak dapat dijelaskan secara tekstual dengan makna yang sebenarnya. Oleh karena itu, Tampubolon menggunakan istilah kemampuan membaca karena kecepatan membaca yang efektif harus sejalan dengan pemahaman isi. Komalasari (2014: 13) menjelaskan bahwa membaca cepat merupakan kegiatan ketika mata bergerak lebih cepat namun dapat memperhatikan informasi-informasi yang ada dalam tulisan.

Di sisi lain, minat baca di Indonesia tergolong sangat rendah. Data pertama dimuat oleh detiknews yaitu hasil penelitian yang dilakukan oleh PISA (Program for International Student Assesment) pada tahun 2015. Penelitian tersebut diambil dari 70 negara dan Indonesia berada di peringkat 62. Responden yang digunakan adalah anak-anak sekolah usia 15 tahun yang jumlahnya sekitar 540 ribu anak.
Rendahnya minat baca di Indonesia diperkuat oleh riset pada tahun 2016 oleh UNESCO yaitu organisasi pendidikan yang membahas tentang ilmu pengetahuan dan kebudayaan PBB. Fakta menunjukkan bahwa Indonesia berada di peringkat 60 dari 61 hasil studi tersebut dipublikasikan dengan nama The World's Most Literature Nations. Menurut UNESCO minat baca di Indonesia hanya $0,001 \%$ jika dikalkulasikan hanya 1 dari 1.000 orang di Indonesia yang rajin membaca.

Jumlah pengguna smartphone yang intens di Indonesia mencapai lebih dari 100 juta orang. Hal yang memprihatinkan lagi meski minta baca buku tergolong rendah, tapi masyarakat Indonesia dapat menatap layar smartphone kurang lebihnya 9 jam dalam sehari data tersebut diungkap oleh wearesocial pada Januari 2017. Berdasarkan riset semiocast yaitu sebuah lembaga independen di Paris, Indonesia berada di urutan ke 5 dunia sebagai negara paling banyak berkomentar di media sosial. Data tersebut diukur dari keaktifan penggunaan twitter di ibukota yang bahkan lebih padat dari Tokyo dan New York.

Akibat rendahnya minat baca, tetapi banyak berkomentar di sosial media tentunya yang terjadi adalah

BASASTRA Jurnal Bahasa, Sastra, dan Pengajarannya

Volume 9 Nomor 1, April 2021, P-ISSN 2302-6405, E-ISSN 2714-9765 
komentar tanpa dilandasi pengetahuan. Hal itu pula yang sering kali menyebabkan terjadinya kesalahan penerimaan dalam mencerna informasi, maka dari itu hal yang tidak kalah penting dengan minat baca yaitu daya baca. Tentunya daya baca memiliki kaitan erat dengan kecepatan efektif membaca, karena kecepatan efektif membaca bukan sekadar membaca dengan cepat, melainkan pemahaman terhadap isi bacaan juga diukur untuk mengetahui daya baca seseorang. Namun, untuk mencerna informasi mendalam tentunya diperlukan pemahaman lebih lanjut atau pemikiran kritis.

Menurut Albert (dalam Tarigan, 2015: 92) membaca kritis adalah membaca yang dilakukan tidak semena-mena mencari kesalahan namun dilakukan secara bijak. Membaca tahap ini dilakukan dengan tenggang hati, mendalam, evaluatif, serta analitis. Pada tahap ini pembaca dituntut untuk menerapkan proses analitik, sintetik, dan evaluatif (Sultan, 2018: 4) Jadi, untuk dapat mencerna bahan bacaan diperlukan waktu yang relatif lama.

Kemampuan membaca kritis berkaitan erat dengan kesadaran bagaimana bahasa dimanipulasi oleh penulis, maka dari itu membaca kritis diperlukan kejelian untuk mengetahui maksud penulis (Subadiyono, 2017: 58). Menurut Pratama (2016) membaca analitis yaitu membaca untuk meningkatkan pemikiran dan pemahaman melalui membaca buku. Oleh karena itu, membaca kritis adalah tahapan membaca lanjut dengan mendalami dan memahami bahan bacaan dengan sebaik mungkin.

Berdasarkan latar belakang yang telah dipaparkan muncul hipotesis bahwa kecepatan efektif membaca adalah kegiatan memahami isi bacaan dalam waktu yang relatif singkat, sedangkan untuk membaca kritis memerlukan waktu yang relatif lama agar dapat mencerna hasil bacaan dengan baik. Walaupun demikian, apabila hasil kecepatan efektif membaca dinilai baik berarti responden dapat memahami isi bacaan dengan baik dan tentunya hasil bacaan tersebut jika sudah dipahami, akan mudah pula untuk dicerna. Jadi, penelitian ini dilakukan untuk menemukan hubungan atau korelasi setelah membaca dengan cepat lalu mengimplementasikannya dalam menyintesis hasil bacaan.

Hipotesis yang muncul pada penelitian ini yaitu terdapat hubungan antara kecepatan efektif membaca dengan kemampuan menyintesis bahan bacaan, artinya hasil kecepatan efektif membaca akan berbanding lurus dengan kemampuan menyintesis hasil bacaan.

Beberapa hal yang telah dipaparkan sebelumnya merupakan hal yang melatarbelakangi penelitian ini yaitu untuk mengukur korelasi antara kecepatan efektif membaca dengan membaca kritis dilihat dari hasil sintesis terhadap bahan bacaan. Populasi yang akan dijadikan objek pada penelitian ini yaitu siswa setingkat SMA (Madrasah Aliyah Negeri) karena memuat KD 11.1 yaitu 
materi mengungkapkan pokok-pokok isi teks dengan membaca cepat. Tuntutan yang harus dipenuhi dalam KD tersebut yaitu membaca cepat teks, menjawab secara benar $75 \%$ dari seluruh pertanyaan yang tersedia, dan mengungkapkan pokok-pokok isi bacaan. Alasan dipilihnya Madrasah Aliyah Negeri (MAN) sebagai objek penelitian karena memiliki mata pelajaran lebih banyak. Selain materi umum di SMA, siswa MAN mendapat beberapa mata pelajaran tambahan yaitu keagaman. Jadi, siswa MAN intens berhadapan dengan bahan bacaan.

Berdasarkan latar belakang yang telah dipaparkan, maka penelitian ini bertujuan untuk mendeskripsikan kecepatan membaca siswa kelas XI di MAN 1 Kota Cirebon, untuk mendeskripsikan hasil menyintesis bacaan siswa kelas XI di MAN 1 Kota Cirebon, untuk mendeskripsikan korelasi antara kecepatan efektif membaca dan hasil sintesis bacaan pada siswa kelas XI di MAN 1 Kota Cirebon.

\section{METODE}

Jenis penelitian ini adalah penelitian kuantitatif. Menurut Noor (2011: 38) penelitian kuantitatif adalah metode yang digunakan untuk menguji teori-teori tertentu dengan cara meneliti hubungan antarvariabel. Menurut Darmawan (2013: 37) penelitian kuantitatif adalah proses menemukan pengetahuan dengan data berupa angka sebagai alat menemukan keterangan terhadap hal yang ingin kita ketahui.
Angka-angka yang yang dijadikan data pada penelitian ini yaitu hasil kecepatan efektif membaca, hasil sintesis hasil bacaan, dan korelasi antara kecepatan efektif membaca dan hasil sintesis bacaan.

Berdasarkan hipotesisnya, penelitian ini masuk pada kategori penelitian studi korelasional. Menurut Emzir (2010: 37) penelitian korelasional mengidentifikasi hubungan dengan sifat prediktif menggunakan teknik korelasi. Menurut Sudijono (dalam Khoiruddin, 2018: 139) korelasional adalah pendekatan dalam penelitian untuk menemukan hubungan yang nantinya akan dianalisis melalui teknik korelasi.

Tempat penelitian berada di MAN 1 Cirebon. Penelitian ini membutuhkan satu kali pengujian kecepatan efektif membaca dan satu kali pengujian hasil sintesis bacaan di masing-masing jurusan. Jadi, total terdapat dua kali pertemuan pada waktu berkisar antara Maret sampai Mei 2020.

Populasi merupakan wilayah generalisasi yang terdiri dari objek atau subjek dengan kuantitas dan karakteristik tertentu yang ditetapkan peneliti untuk dipelajari lalu ditarik kesimpulannya (Sugiyono, 2017: 61). Pada penelitian ini populasi yang akan dijadikan sumber dapat penelitian adalah populasi homogen. Dilihat dari jumlah populasi, maka sumber data yang digunakan pada penelitian ini dari jurusan IPA karena memiliki jumlah lebih banyak dari IPS dengan total 164 siswa. 
Teknik sampling yang digunakan yaitu teknik simple random sampling atau biasa disebut dengan teknik pengambilan sampel secara sederhana. Dikatakan pengambilan secara sederhana karena sampel diambil secara acak tanpa memperhatikan strata dalam populasi tersebut (Sugiyono, 2017: 63). Pada penelitian ini digunakan sebanyak 36 responden dari 164 total jumlah responden yang homogen. Jadi, 36 responden sudah dikatakan cukup untuk penelitian korelasional.

$$
\text { Instrumen pertama yang }
$$

digunakan yaitu teks bacaan seputar puisi, stilistika, dan bahasa kias menurut beberapa ahli dengan jumlah keseluruhan kata sebanyak 1.000 kata. Digunakannya tiga subjudul dalam bahan bacaan guna mengonstruksi pemahaman agar mencapai ranah kognitif C6. Teks terlebih dahulu diuji kelayakannya. Menurut Ahuja (2010: 76) berbagai penelitian menunjukkan bahwa agar bahan bacaan sesuai dan layak digunakan dalam level intruksional (studi yang diawasi), siswa setidaknya mampu menjawab $75 \%$ dari bahan-bahan yang bersangkutan. Untuk mencapai level independen (studi mandiri) siswa harus mampu menjawab 90\% dari pertanyaan. Dari hasil uji tingkat keterbacaan, siswa mampu menjawab $17,58 \%$ dari 20 soal, dengan total rata-rata sebanyak $87,88 \%$. Karena angka tersebut sudah sangat mendekati $90 \%$ maka tingkat keterbacaan teks dianggap layak untuk level independen (studi mandiri).
Tes kedua pemahaman isi bertujuan untuk menunjukkan bahwa responden telah memiliki pengertian memadai dalam mengorganisasikan dan menyusun materi-materi yang telah diketahui (Efsyarbani, 2013: 32). Untuk menguji pemahaman isi, tes yang digunakan yaitu soal objektif berupa tes pilihan ganda sebanyak 20 soal dengan tingkat kesulitan $\mathrm{C} 1$ sampai C4 dalam ranah kognitif taksonomi Bloom. Sebanyak 3 butir soal $\mathrm{C} 1,2$ butir soal $\mathrm{C} 2,8$ butir $\mathrm{C} 3,7$ butir $\mathrm{C} 4$.

Untuk menguji kemampuan menyintesis digunakan tes uraian objektif adalah perpaduan antara tes uraian dan tes objektif. Tingkatan soal yang digunakan yaitu 3 butir soal C5 dengan kata kunci menyimpulkan dan 1 butir C6 menghubungkan.

Butir soal dinyatakan valid apabila $r_{\text {hitung }}$ lebih besar dari $\mathrm{r}_{\text {tabel. }}$. Sebaliknya jika $r_{\text {hitung }}$ kurang dari $r_{\text {tabel }}$ maka soal dinyatakan gugur. Untuk nilai $\mathrm{r}_{\text {tabel }} \mathrm{N}=33$ pada taraf signifikansi $5 \%$ adalah 0,344 . Rangkuman hasil uji validitas instrumen adalah sebagai berikut.

Tabel 1. Uji Validitas

\begin{tabular}{ccc}
\hline No soal & $\begin{array}{c}\mathbf{r} \\
\text { hitung }\end{array}$ & Keterangan \\
\hline 1 & .606 & Valid \\
\hline 2 & .365 & Valid \\
\hline 3 & .606 & Valid \\
\hline 4 & .606 & Valid \\
\hline 5 & .606 & Valid \\
\hline 6 & .357 & Valid \\
\hline 7 & .897 & Valid \\
\hline 8 & .915 & Valid \\
\hline 9 & .898 & Valid \\
\hline 10 & .325 & Tidak valid \\
\hline
\end{tabular}




\begin{tabular}{ccc}
\hline 11 & .552 & Valid \\
\hline 12 & .730 & Valid \\
\hline 13 & .862 & Valid \\
\hline 14 & .806 & Valid \\
\hline 15 & .915 & Valid \\
\hline 16 & .791 & Valid \\
\hline 17 & .808 & Valid \\
\hline 18 & .897 & Valid \\
\hline 19 & .593 & Valid \\
\hline 20 & .165 & Tidak valid \\
\hline \multicolumn{3}{c}{ Berdasarkan hasil uji validitas }
\end{tabular}

soal yang dinyatakan valid sebanyak 18 butir soal dan 2 soal dinyatakan tidak valid. Soal yang tidak valid akan direvisi dan diturunkan levelnya agar tetap genap 20 soal.

Instrumen menggunakan tes pilihan ganda dan jawaban yang dibutuhkan bukan jawaban berskala, melainkan jawaban dikotomis yaitu jawaban "benar" atau "salah", maka uji reliabilitas menggunakan teknik belah dua atau split half Spearman Brown. Hasil uji reliabilitasnya adalah sebagai berikut.

Tabel 2. Uji Reliabilitas

\begin{tabular}{rlc}
\hline \multicolumn{3}{c}{ Reliability Statistics } \\
\hline Spearman & $\begin{array}{l}\text { Equal } \\
\text { Length }\end{array}$ & .946 \\
\hline Brown Coefficient & $\begin{array}{l}\text { Unequal } \\
\text { Length }\end{array}$ & .946 \\
\hline $\begin{array}{l}\text { Guttman Split-Half } \\
\text { Coefficient }\end{array}$ & & .905 \\
\hline Dari data & di atas & dapat
\end{tabular}

dismpulkan bahwa instrumen sangat reliabel karena mendekati 1.00 .

Data dianalisis dengan menggunakan teknik analisis kecepatan membaca untuk menggambarkan hasil kecepatan efektif membaca. Untuk menghitung kecepatan efektif membaca diperlukan kecepatan membaca dan pemahaman isi, setelah itu dipaparkan hasil dari kecepatan efektif membaca kemudian dideskripsikan. Sesuai dengan pendapat beberapa ahli yang telah dijelaskan pada landasan teori bahwa tingkat SLTA setidaknya minimal memiliki kecepatan membaca 250 kata/menit dan pemahaman isi sebanyak 70\%, maka kecepatan efektif membaca yang didapat adalah 175 kpm. Artinya, jika pemahaman isi yang didapat $100 \%$ maka akan didapat nilai maksimal yaitu $250 \mathrm{kpm}$. Bentuk penghitungannya adalah sebagai berikut.

$250 \times 70 \%=175$

jika pemahaman isi $100 \%$,

maka $250 \times 100: 100=250$

Pada penelitian ini teks memiliki jumlah 1.000 kata. Jika dihitung per menit maka minimal teks dibaca dalam waktu 4 menit dengan pemahaman isi $70 \%$ dan akan didapat hasil kecepatan efektif membaca $175 \mathrm{kpm}$. Apabila pemahaman isi $100 \%$ maka nilai maksimal 1.000 .

$$
\begin{aligned}
& 1.000 \times 70 \%: 4=175 \text { jika } \\
& \text { pemahaman isi } 100 \%, \text { maka } \\
& (1.000 \times 100):(4 \times 100)=250
\end{aligned}
$$

Agar mendapat angka kecepatan membaca lebih detail, maka waktu tempuh dalam membaca akan dihitung dengan detik. Sebelum dilanjutkan pada tahap penghitungan dengan menggunakan statistik, karena hasil kecepatan efektif dengan skor minimal 175 dan maksimal 250 terlalu banyak menggunakan digit angka dan akan menimbulkan terlalu banyaknya 
varians skor item, maka data akan dikonversi menjadi nilai akhir maksimal $=100$ dengan cara KEM dibagi 2,5. Penghitungannya adalah sebagai berikut:

$175: 2,5=70$ jika pemahaman isi $100 \%$, maka $250: 2,5=100$

Sesuai pendapat Widiatmoko (dalam Efsyarbani, 2013: 14) bahwa tingkat SLTA kecepatan efektif membaca memiliki rentang antara 175$245 \mathrm{kpm}$. Maka, hasil kecepatan efektif membaca yang melewati angka 250 kpm akan dieliminasi dan tidak dilanjutkan pada tahap selanjutnya karena akan melebihi nilai maksimal dan terlalu jauh melewati jenjang SLTA.

Untuk menganalisis tes uraian objektif dilakukan dengan menghubungkan dan membandingkan kata kunci jawaban siswa dengan jawaban menurut para ahli. Jadi, pada analisis ini padanan kata berlaku dan akan dianggap benar jika kata memiliki makna sama dengan ketentuan sebagai berikut:

(a) Jika responden mampu menjawab dengan 1 kata kunci atau lebih dari 3 ahli yang berbeda, maka mendapat poin 3 .

(b) Jika responden mampu menjawab dengan 1 kata kunci atau lebih dari 2 ahli yang berbeda, maka mendapat poin 2 .

(c) Jika responden mampu menjawab dengan 1 kata kunci atau lebih hanya dari 1 ahli, maka hanya mendapat skor 1 . (d) Padanan dari kata kunci berlaku untuk diberikan skor.

Untuk pertanyaan nomor 4 dengan indikator menghubungkan, karena untuk pertanyaan nomor 4 tergantung pada pertanyaan nomor 1, 2, dan 3, maka teknik penilaiannya digunakan dimulai dari skor 2. Jika responden mampu menghubungkan 2 tema, maka poin yang didapat 2. Jika responden mampu menghubungkan 3 tema, maka poin yang didapat 3.Karena soal sebanyak 4 butir dan poin maksimal 3, maka untuk mendapatkan nilai akhir adalah dengan penghitungan sebagai berikut.

$4 \times 3=12$

(Jumlah butir soal $x$ poin maksimal/butir $=$ poin maksimal $)$

$12 \times 100: 12=100$ (nilai maksimal)

Setelah kedua variabel didapat lalu diuji prasyarat analisis dengan uji normalitas dan linearitas. Langkah selanjutnya teknik analisis data menggunakan teknik analisis korelasional. Teknik analisis korelasional adalah teknik analisis statistik mengenai hubungan antara dua variabel atau lebih. Korelasional bertujuan untuk menggambarkan hubungan dari data yang ingin dihubungkan (Annisa, 2017: 13).

Hipotesis pada penelitian ini masuk kategori hipotesis asosiatif, karena akan meneliti hubungan atau korelasi. Hipotesisnya adalah sebagai berikut:

Ho : $r_{x y}=0$

Ha $: r_{x y} \neq 0$ 
Ho: Tidak terdapat hubungan antara hasil kecepatan efektif membaca dengan hasil sintesis bacaan.

Ha: Terdapat hubungan antara hasil kecepatan efektif membaca dengan hasil sintesis bacaan.

\section{HASIL DAN PEMBAHASAN}

\section{Kecepatan Efektif Membaca}

Dari hasil penelitian diperoleh skor kecepatan efektif membaca tertinggi sebesar $280 \mathrm{kpm}$ dan skor terendah yaitu $28 \mathrm{kpm}$. Responden dengan nilai tinggi di atas batas taraf terdapat 2 responden yaitu responden nomor 1 senilai $280 \mathrm{kpm}$ dan responden nomor 21 senilai $279 \mathrm{kpm}$. Kedua data tersebut jika dibagi 2,5 untuk mendapat skor tertinggi $=100$ akan berada pada skor 112, sedangkan skor tertinggi untuk hasil sintesis adalah 100. Jadi, kedua data tersebut dieliminasi dan yang akan dilanjutkan untuk tahap pengujian selanjutnya adalah 34 responden.

Setelah data dari 34 responden dikonversi, maka skor tertinggi yang mungkin akan didapat siswa adalah 100 dan terendah adalah 0. Skor tertinggi untuk kecepatan efektif membaca pada siswa kelas XI di MAN 1 Cirebon adalah 85 dan skor terendah adalah 11. Penghitungan dilakukan dengan program SPSS 25. Hasil penghitungan data tersebut diperoleh rata-rata (mean) sebesar 53,21; nilai tengah (median) sebesar 57,50; modus (mode) sebesar 44 dan standar deviasi sebesar 21,17. Data statistik hasil penghitungan dan tabel distribusi frekuensi, dan histogram kecepatan efektif membaca (KEM) adalah sebagai berikut.

Tabel 3. Penghitungan Statistik Kecepatan Efektif Membaca Siswa Kelas XI di MAN 1 Cirebon

\begin{tabular}{llr}
\hline \multicolumn{2}{c}{ Statistics } \\
\hline KEM & & \\
\hline \multirow{2}{*}{$\mathrm{N}$} & Valid & 34 \\
\cline { 2 - 3 } & Missing & 0 \\
\hline Mean & 53.21 \\
\hline Std. Error of & 3.630 \\
Mean & \\
\hline Median & 57.50 \\
\hline Mode & $44^{\mathrm{a}}$ \\
\hline Std. Deviation & & 21.169 \\
\hline
\end{tabular}

Diagram 1. Histogram Kecepatan Efektif Membaca

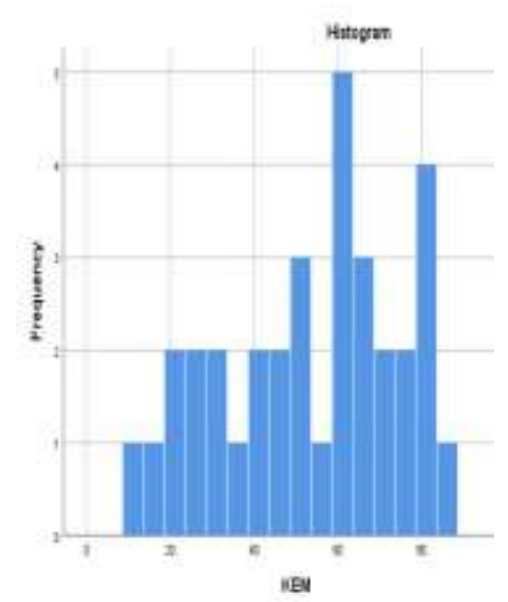

Dari data di atas dapat diketahui bahwa skor kecepatan efektif membaca memiliki banyak varians nilai, karena waktu membaca setiap individu tentunya akan berbeda. Dari data di atas terdapat 33 varians berbeda dengan nilai dengan frekuensi tertinggi berada pada skor 44, 73, dan 74 sebanyak 2 responden. Frekuensi lainnya hanya berjumlah 1 responden. Untuk menganalisis atau mengidentifikasi 
kategori tinggi-rendahnya skor variabel, diperlukan nilai mean, dan nilai standar deviasi ideal. Pengkategorian nilai kecepatan efektif membaca dibagi menjadi tiga kriteria sebagai berikut:

(a) Tinggi > (Mi + 1SDi)

(b) Sedang, antar (Mi - 1SDi) sampai $(\mathrm{Mi}+1 \mathrm{SDi})$

(c) Rendah $<\mathrm{Mi}-1 \mathrm{SDi}$

Keterangan

$\mathrm{Mi}=$ rata-rata ideal $\{12$ (skor tertinggi + skor terendah) $\}$

SDi $=$ standar deviasi ideal $\{16$ (skor tertinggi + skor terendah) $\}$

Berdasarkan hasil kecepatan efektif membaca diperoleh skor tertinggi 85 dan terendah 11. Oleh karena itu, nilai rata-rata dan standar deviasi ideal dapat dihitung dengan rumus berikut:

$\mathrm{Mi}=\{12(85+11)\}=48$

$\mathrm{SDi}=\{16(85+11)\}=16$

Berdasarkan penghitungan nilai rata-rata dan standar deviasi ideal, maka kriteria pengkategorian dapat disusun sebagai berikut:

(a) Tinggi $>(48+16)=64$

(b) Sedang, antara 32 sampai 64

(c) Rendah $<(48-16)=32$

Berdasarkan data dan penghitungan dengan skor ideal, maka dapat dibuat tabel distribusi frekuensi untuk kecepatan efektif membaca sebagai berikut:

Tabel 4. Kecepatan Efektif Membaca Berdasarkan Skor Ideal

\begin{tabular}{cccc}
\hline Kategori & Interval & $\begin{array}{c}\text { Freku } \\
\text { ensi }\end{array}$ & $\begin{array}{c}\text { Persenta } \\
\text { se }\end{array}$ \\
\hline Tinggi & $>64$ & 12 & $35,29 \%$ \\
\hline Sedang & 32 s/d 64 & 15 & $44,12 \%$ \\
\hline
\end{tabular}

\begin{tabular}{rrcc}
\hline Rendah & $<32$ & 7 & $20,59 \%$ \\
\hline Jumlah & 34 & $100 \%$ \\
\hline Berdasarkan & data & di & atas,
\end{tabular}
kecepatan efektif membaca di MAN 1 Cirebon pada kategori tinggi sebanyak 12 responden $(35,29 \%)$. Untuk kategori sedang sebanyak 15 reponden $(44,12 \%)$. Untuk kategori rendah sebanyak 7 responden (20,59\%). Karena frekuensi terbanyak berada pada kategori sedang dapat disimpulkan bahwa kecepatan efektif membaca oleh siswa kelas XI di MAN 1 Cirebon berada pada kategori sedang.

Dari beberapa data di atas, dapat dijabarkan bahwa kecepatan efektif membaca siswa kelas XI di MAN 1 Cirebon berada pada kategori sedang, namun penghitungan tersebut bukan diambil mentah dari rumus KEM.

Karena jika standar dengan menggunakan rumus KEM maka standar minimal berada pada kategori tinggi. Jadi, untuk penghitungan tersebut dapat disimpulkan bahwa kecepatan efektif membaca siswa kelas XI di MAN 1 Cirebon berada pada ketegori sedang, dengan standar KEM berada pada kategori di bawah ratarata.

Ada banyak faktor penyebab nilai kecepatan efektif membaca berada di bawah standar KEM pada tingkat yang seharusnya yaitu tingkat SLTA. Faktor pertama yang dapat dijadikan penyebab rendahnya KEM adalah waktu tempuh. Ketika uji instrumen tingkat keselarasan teks dengan soal untuk diujikan terbilang tinggi karena tingkat keterbacaan dilihat dari pemahaman isi setinggi $87 \%$. Setelah 
dihitung dengan jangka waktu ketika membaca hasil akhir menjadi turun dan didapat lebih dari 69\% responden berada pada tingkat membaca rendah, dengan kata lain waktu menjadi fokus utama dalam membaca. Artinya yang paling dominan memengaruhi rendahnya KEM adalah waktu.

Untuk mendapatkan pemahaman dalam kegiatan membaca tentunya membutuhkan waktu yang relatif lama, namun tuntutan membaca seperti yang dikemukakan oleh Tampubolon (2015: 7) bahwa standar minimum kecepatan membaca siswa tingkat SLTA adalah 250 kata per menit dan pemahaman isi setinggi $70 \%$, dengan kata lain standar minimum tingkat SLTA adalah 175 kpm. Jadi, siswa dituntut untuk mendapatkan pemahaman isi dalam waktu yang relatif singkat jika dalam standar KEM.

Faktor kedua yang memengaruhi kecepatan efektif membaca adalah pengetahuan terhadap bacaan. Jika siswa lebih intens dalam membaca tentunya pengetahuannya akan bertambah dan akan mudah dalam memahami bahan bacaan jika sebelumnya sudah memiliki pengetahuan tentang topik dalam suatu teks. Tentunya hal tersebut akan meminimalisir waktu tempuh dalam membaca karena tidak perlu mendalami bacaan tersebut. Jadi, siswa hanya perlu menggali informasi yang didapat tidak perlu terlalu mendalami bahan bacaan untuk mendapatkan pemahaman isi.

Faktor ketiga yang memengaruhi hasil tersebut adalah kurangnya pengawasan. Karena data diambil dengan teknik daring, maka siswa tidak dapat diawasi secara langsung dalam teknik daring. Jadi, siswa dapat menggunakan waktu tanpa batasan sesuai kehendak sendiri sebelum mencantumkannya dalam catatan waktu.

Kebiasaan dalam membaca harus ditingkatkan, karena dalam kegiatan membaca membutuhkan pengetahuan yang lebih agar dapat mengefisiensi dan mengefektifkan waktu dalam membaca. Siswa harus memiliki dorongan untuk menjadikan membaca sebagai kebiasaan. Karena pengaruh dari membaca sangat besar sebagai tambahan ilmu pengetahuan. Jadi, kesimpulannya kefektifan dan efisiensi waktu dalam membaca pada siswa kelas XI di MAN 1 Cirebon perlu ditingkatkan.

\section{Menyintesis Bacaan}

Menurut Simmons (dalam Priyatni, 2014: 3) keterampilan kritis merupakan keterampilan membuat simpulan dari hasil analisis. MeriamWebster (dalam Nurhasanah dkk., 2019: 58) mengemukakan bahwa secara etimologis istilah sintesis berasal dari bahasa Yunani syntithenai yang berarti menempatkan atau meletakkan. Lebih lanjutnya, sintesis diartikan sebagai kombinasi atau komposisi dari beberapa bagian yang membentuk satu kesatuan. Hasil sintesis bacaan menjadi variabel terikat dalam penelitian ini. Data untuk mendapatkan skor kemampuan menyintesis bacaan digunakan tes 
uraian objektif. Skor maksimal yang mungkin dapat diperoleh siswa adalah 100 dan terendah adalah 0. Dari hasil penelitian diperoleh data hasil menyintesis bacaan dengan skor tertinggi adalah 92 .

Tabel 5. Penghitungan Statistik Menyintesis Bacaan

\begin{tabular}{lr}
\hline \multicolumn{2}{c}{ Statistics } \\
\hline Sintesis & 34 \\
\hline Valid & 0 \\
\hline Missing & 47.79 \\
\hline Mean & 2.876 \\
\hline Std. Error of & \\
\hline Mean & 42.00 \\
\hline Median & 42 \\
\hline Mode & 16.769 \\
\hline Std. Deviation
\end{tabular}

Dari hasil penelitian diperoleh hasil menyintesis bacaan dengan skor tertinggi adalah 92 dan skor terendah 17. Berdasarkan data tersebut diperoleh rata-rata (mean) sebesar 47,79; nilai tengah (median) sebesar 42,00; modus (mode) sebesar 42, dan standar deviasi sebesar 16,769. Penghitungan dibantu dengan SPSS 25. Hasil penghitungan data statistik dan histogram hasil menyintesis bacaan adalah sebagai berikut.

Diagram 2. Histogram Menyintesis Bacaan

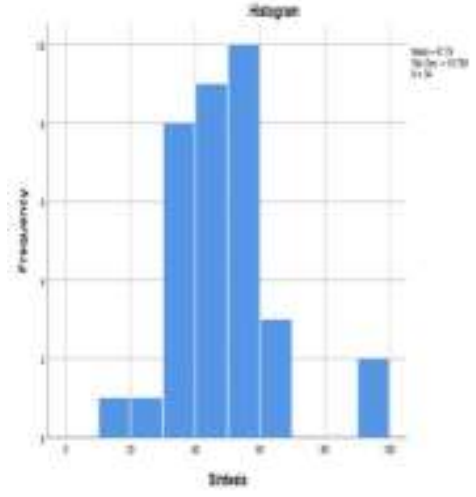

Dari data di atas dapat diketahui bahwa frekuensi terbesar skor hasil menyintesis bacaan berada pada nilai 42 dengan frekuensi 9 responden. Frekuensi terendah berada pada nilai 17 dan 25 sebanyak 1 responden. Untuk menganalisis atau mengidentifikasi kategori tinggi rendahnya skor variabel, diperlukan nilai mean, dan nilai standar deviasi ideal. Nilai hasil menyintesis bacaan dibagi menjadi tiga kriteria sebagai berikut:

(a) Tinggi $>(\mathrm{Mi}+1 \mathrm{SDi})$

(b) Sedang, antara Mi - 1SDi) sampai (Mi + 1SDi)

(c) Rendah $<$ Mi - 1SDi

Keterangan

$\mathrm{Mi}=$ rata-rata ideal $\{12$ (skor tertinggi + skor terendah) $\}$

SDi $=$ standar deviasia ideal $\{16$ (skor tertinggi + skor terendah) \}

(Sudijono dalam Amalia, 2013: 50).

Berdasarkan hasil menyintesis bacaan diperoleh skor tertinggi 92 dan terendah 17 . Oleh karena itu, nilai ratarata dan standar deviasi ideal dapat dihitung dengan rumus berikut:

$\mathrm{Mi}=\{12(92+17)\}=54,5$

$\mathrm{SDi}=\{16(92+17)\}=18,2$

Berdasarkan penghitungan nilai rata-rata dan standar deviasi ideal, 
maka kriteria pengkategorian dapat disusun sebagai berikut:
(a) Tinggi $>(54,5+18,2)=72,7$
(b)Sedang, antara 36,3 sampai 72,7
(c) Rendah $<(54,5-18,2)=36,3$

Berdasarkan

data dan

penghitungan dengan skor ideal, maka dapat dibuat tabel distribusi frekuensi untuk hasil menyintesis bacaan sebagai berikut.

Tabel 6. Kemampuan Menyintesis

\begin{tabular}{|c|c|c|c|}
\hline \multicolumn{4}{|c|}{ Berdasarkan Skor Ideal } \\
\hline Kategori & Interval & $\begin{array}{c}\text { Freku } \\
\text { ensi }\end{array}$ & Persentase \\
\hline Tinggi & $>72,7$ & 2 & $5,88 \%$ \\
\hline \multirow[t]{2}{*}{ Sedang } & $36,3 \mathrm{~s} / \mathrm{d}$ & 22 & $64,71 \%$ \\
\hline & 72,7 & & \\
\hline Rendah & $<36,3$ & 10 & $29,41 \%$ \\
\hline & lah & 34 & $100 \%$ \\
\hline
\end{tabular}

Berdasarkan data di atas, hasil menyintesis bacaan di MAN 1 Cirebon pada kategori tinggi sebanyak 2 responden $(5,88 \%)$. Untuk kategori sedang sebanyak 15 reponden $(64,71 \%)$. Untuk kategori rendah sebanyak 7 responden $(29,41 \%)$. Karena frekuensi terbanyak berada pada kategori sedang, maka dapat disimpulkan bahwa kemampuan menyintesis bacaan oleh siswa kelas XI di MAN 1 Cirebon berada pada kategori sedang.

Berdasarkan deskripsi hasil penelitian pada siswa kelas XI di MAN 1 Cirebon berdasarkan skor ideal, dapat diketahui bahwa skor dengan frekuensi berada pada kategori sedang sebanyak
22 responden (64,71\%). Untuk frekuensi paling sedikit berada pada kategori tinggi yang hanya sebanyak 2 reponden $(5,88 \%)$. Untuk frekuensi pada kategori rendah sebanyak 7 responden $(29,41 \%)$.

Dari hasil analisis data tersebut dapat disimpulkan bahwa kemampuan menyintesis bacaan siswa kelas XI di MAN 1 Cirebon berada pada kategori menengah ke bawah. Hal tersebut terlihat dari siswa yang mendapat skor tinggi hanya 2 orang dengan nilai $>72$, kedua siswa tersebut berada pada nilai 92 termasuk kategori sangat tinggi, 22 orang pada kategori sedang, dan 7 orang berada pada kategori rendah. Karena frekuensi terbanyak berada pada kategori sedang, maka dapat disimpulkan bahwa kemampuan menyintesis bacaan siswa kelas XI di MAN 1 Cirebon berada pada kategori sedang.

Kemampuan menyintesis merupakan bagian dari kemampuan membaca kritis. Apabila seseorang telah menguasai kemampuan membaca kritis, maka orang tersebut dapat memahami bahan bacaan secara mendalam. Salah satu cara mengukur kemampuan membaca kritis yaitu dengan cara menyintesis bacaan. Ketika orang tersebut mampu menghubungkan beberapa sumber yang ada lalu menarik kesimpulan baru. Pada penelitian ini kemampuan menyintesis siswa kelas XI di MAN 1 Cirebon berada pada kategori menengah ke bawah. Karena dari 34 responden yang diuji hanya 2 
responden yang mencapai kategori tinggi.

Ada beberapa faktor yang menyebabkan terjadinya hal tersebut. Faktor-faktor yang memengaruhi hal tersebut tidak jauh beda dengan faktor yang memengaruhi kecepatan efektif membaca, di antaranya waktu, wawasan terhadap bahan bacaan, dan kurangnya pengawasan karena data tersebut juga diambil melalui daring. Dilihat dari segi waktu seharusnya skor menyintesis akan berada pada kategori tinggi jika memang kegiatan berpikir kritis membutuhkan waktu yang relatif lama, namun kemampuan menyintesis pada penelitian ini berada pada kategori sedang.

\section{Uji Prasyarat Analisis}

Setelah didapat hasil kecepatan efektif membaca dan hasil menyintesis bacaan langkah selanjutnya dilanjutkan dengan tahap prasyarat analisis yaitu denan uji normalitas dan uji linearitas. Berikut hasil uji normalitas dan uji linearitas.

Tabel 7. Uji Normalitas One-Sample Kolmogorov-Smirnov Test

\begin{tabular}{llrr}
\hline \multicolumn{4}{c}{ Kolmogorov-Smirnov Test } \\
& \multicolumn{3}{c}{$\mathrm{X}$} \\
\hline & $\mathrm{N}$ & $\mathrm{Y}$ \\
\hline & & 34 & 34 \\
\hline Normal & Mean & 53.21 & 47.79 \\
\hline Parameters ${ }^{a, b}$ & $\begin{array}{l}\text { Std.Devi } \\
\text { ation }\end{array}$ & 21.169 & 16.769 \\
& Absolute & .108 & .194 \\
\cline { 2 - 4 } Most & Positive & .077 & .194 \\
\cline { 2 - 4 } Extreme & Negative & -.108 & -.130 \\
Differen & & & \\
ces & & & \\
\hline
\end{tabular}

\begin{tabular}{|c|c|c|}
\hline Test Statistic & .108 & .194 \\
\hline \multirow[t]{3}{*}{ Asymp. Sig. (2-tailed) } & $.200^{\mathrm{c}, \mathrm{d}}$ & $.002^{c}$ \\
\hline & $\begin{array}{l}\text { Sig. (2- } \\
\text { tailed) }\end{array}$ & \\
\hline & $\overline{\mathrm{N}}$ & 34 \\
\hline $\begin{array}{l}\text { Hasil } \\
\text { sintesis }\end{array}$ & Correlation & .076 \\
\hline & Coefficient & \\
\hline & $\begin{array}{l}\text { Sig. }(2- \\
\text { tailed })\end{array}$ & .669 \\
\hline & $\mathrm{N}$ & 34 \\
\hline
\end{tabular}

berdistribusi normal, sedangkan variabel y tidak berdistribusi normal.

Tabel 8. Uji Linearitas

\begin{tabular}{cccc}
\hline \multirow{2}{*}{ Variabel } & \multirow{2}{*}{$\mathrm{Db}$} & \multicolumn{2}{c}{ Harga $\mathrm{F}$} \\
\cline { 3 - 4 } & & Fhitung & Ftabel \\
\hline $\mathrm{X}-\mathrm{Y}$ & $1 / 28$ & 0,631 & 4,13
\end{tabular}

Dari data di atas terlihat bahwa hubungan antara variabel bebas dan terikat berpola linear karena $f_{\text {hitung }}<f_{\text {tabel }}$.

Statistik yang digunakan statistik nonparametrik dengan teknik Spearman Rank. Analisis korelasional bertujuan untuk menemukan hubungan antarvariabel menggunakan statistik korelasi agar dapat diperoleh besarnya koefisien korelasi antara variabel yang diteliti (Suharsaputra, 2012: 124). Jadi, setelah didapat kedua variabel yaitu kecepatan efektif membaca dan hasil menyintesis bacaan kemudian dihitung koefisien korelasinya.

Pengujian hipotesis dilakukan dengan teknik analisis korelasional untuk menentukan kuat atau lemahnya hubungan antarvariabel. Karena dalam uji prasyarat analisis, salah satu variabel berdistribusi tidak normal yaitu variabel y, maka teknik analisis 
korelasi yang digunakan menggunakan teknik analisis nonparamerik yaitu dengan teknik korelasi Spearman Rank. Berikut adalah hasil penghitungan teknik korelasi Spearman Rank dengan bantuan SPSS 25.

\begin{tabular}{lll}
\multicolumn{3}{c}{ Tabel 9. Hasil Korelasi Spearman } \\
\\
Rank \\
\hline $\begin{array}{l}\text { Spearma Kem } \\
n \text { 's rho }\end{array}$ & $\begin{array}{l}\text { Correlation } \\
\text { Coefficient }\end{array}$ & 0,076 \\
& &
\end{tabular}

\begin{tabular}{llr} 
& \multicolumn{2}{l}{ Sig. (2-tailed) } \\
\cline { 2 - 3 } & $\mathrm{N}$ & 34 \\
\hline $\begin{array}{ll}\text { Hasil } \\
\text { sintesis }\end{array}$ & Correlation & .076 \\
& Coefficient & \\
\cline { 2 - 2 } & & \\
& Sig. (2-tailed) & .669 \\
& 34
\end{tabular}

Dari tabel di atas, dapat diketahui bahwa teknik penghitungan korelasi Spearman Rank menghasilkan nilai rxy sebesar 0,076 . Untuk mengetahui harga t signifikan atau tidak, maka perlu dibandingkan dengan $t$ tabel. Untuk uji dua pihak dengan taraf signifikasi $5 \%$ dengan $\mathrm{dk}=\mathrm{n}-2(34-2=32)$ maka nilai $\mathrm{t}$ tabel yang didapat yaitu 2,021. Karena harga thitung lebih kecil dari tabel $(0,076$ $<2,021)$, maka Ho diterima dan $\mathrm{Ha}$ ditolak, artinya tidak terdapat hubungan yang signifikan antara kecepatan efektif membaca dengan kemampuan menyintesis hasil bacaan. Berikut adalah tabel derajat hubungan untuk memberikan interpretasi terhadap koefisien korelasi.

Jika dikonsultasikan dengan tabel derajat hubungan 0,076 berada pada interval $0,00-0,199$. Jadi, dapat disimpulkan bahwa kecepatan efektif membaca dan hasil menyintesis bacaan pada siswa kelas XI di MAN 1 Cirebon memiliki hubungan sangat rendah. Artinya kecepatan efektif membaca tidak terlalu memengaruhi hasil menyintesis, dengan kata lain kemampuan membaca dengan tahap kritis atau mendalami tidak dapat dilakukan dalam waktu yang relatif singkat.

Hasil penghitungan tersebut menjelaskan bahwa hubungan kecepatan efektif membaca dan kemampuan menyintesis bacaan tidak signifikan. Kemampuan menyintesis merupakan lanjutan dari kemampuan membaca kiritis. Untuk melakukan proses berpikir kritis tentunya dibutuhkan waktu yang relatif lama. Walaupun kecepatan efektif membaca tidak sekadar membaca cepat, namun dituntut untuk memahami bahan bacaan, tetapi hal tersebut tidak berlaku untuk mendalami bahan bacaan. Karena kemampuan untuk menyintesis membutuhkan kemampuan berpikir kritis secara mendalam tidak hanya sekadar memahami bacaan. Jadi, untuk dapat menguasai kemampuan membaca kritis yang diimplementasikan dalam menyintesis hasil bacaan, seseorang tidak perlu menguasai kecepatan efektif membaca terlebih dahulu karena hubungan dari keduanya tidak terlalu signifikan.

\section{SIMPULAN}

Berdasarkan data yang diperoleh dan hasil uji statistik, maka simpulan 
dari penelitian ini adalah sebagai berikut.

Kecepatan efektif membaca pada siswa kelas XI di MAN 1 Cirebon pada kategori tinggi sebanyak 12 responden $(35,29 \%)$. Untuk kategori sedang sebanyak 15 reponden (44,12\%). Untuk kategori rendah sebanyak 7 responden $(20,59 \%)$. Kecepatan efektif membaca oleh siswa kelas XI di MAN 1 Cirebon berada pada kategori sedang.

Kemampuan menyintesis bacaan siswa kelas XI di MAN 1 Cirebon frekuensi berada pada kategori sedang sebanyak 22 responden $(64,71 \%)$. Untuk frekuensi berada pada kategori tinggi sebanyak 2 reponden $(5,88 \%)$. Untuk frekuensi pada kategori rendah sebanyak 7 responden $(29,41 \%)$. Kemampuan menyintesis bacaan 11 siswa kelas XI di MAN 1 Cirebon berada pada kategori sedang.

Terdapat korelasi antara kecepatan efektif membaca dan hasil menyintesis bacaan, namun tidak signifikan karena $t_{\text {hitung }}$ yang senilai 0,076 lebih kecil dari tabel yang senilai 2,042. Ketika dibandingkan dengan tabel derajat hubungan nilai koefisien korelasi berada pada tingkat sangat rendah. Jadi, kecepatan efektif membaca tidak memengaruhi kemampuan dalam menyintesis bacaan.

\section{REFERENSI}

Ahuja, P. (2010). Membaca Secara Efektif dan Efisien. Jakarta: Kiblat Buku Utama.
Annisa. (2017). Hubungan Penguasaan Gaya Bahasa Perbandingan Siswa Kelas VII SMP Dwi Tunggal Tanjung Morawa Tahun 2016-2017. Jurnal Pendidikan Bahasa dan Sastra Indonesia, 678, 9-18.

Darmawan, D. (2013). Metode Penelitian Kuantitatif. Bandung: PT Remaja Rosdakarya.

Efsyarbani. (2013). Kajian Kecepatan Efektif Membaca Cepat (KEM) Siswa Kelas XI SMA Plus Negeri 7 Bengkulu Tahun Pelajaran 2012/2013. Skripsi Tidak Dipublikasikan. Universitas Bengkulu.

Emzir. (2010). Metode Penelitian Kuantitatif dan Kualitatif. Jakarta: Rajawali Pers.

Priyatni, E.T. (2014). Pengembangan Bahan Ajar Membaca Kritis Berbasis Intervensi Responsif. Litera, 13 (1), 1-3.

Hayati, N., Atmazak \& Abdurrahman. (2015). Hubungan Keterampilan Membaca Kritis dengan Keterampilan Menulis Artikel Populer Berdasarkan Gaya Belajar Siswa Kelas XI SMA Negeri 5 Padang. Jurnal Bahasa dan Sastra Pembelajaran, 2 (1), 39-48.

Khoiruddin, M. (2018). Pengaruh Program Tahfidzul Qur'an dan Motivasi Belajar terhadap Prestasi Akademik Mahasiswa: Studi Pada Mahasiswa PKD Dan PKP Universitas Djuanda Bogor. Edukasi Islami Jurnal Pendidikan Islam, 7, 131-56.

Komalasari, H. (2014). Melalui Teknik Skimming pada Mata Pelajaran Bahasa Indonesia Siswa Kelas V SD Al-Zahra Indonesia Pamulang pada Tahun Pelajaran. Skripsi Tidak 
Dipublikasikan. UIN Syarif Hidayatullah Jakarta.

Noor, J. (2013). Metodologi Penelitian. Jakarta: Kencana Prenada Media Grup.

Nurhasanah, H.S., Hidayat, E., \& Mulyani, E. (2019). Analisis Kemampuan Sintesis Peserta Didik dengan Menggunakan Model Problem Based Learning Ditinjau dari Self Esteem. Journal Authentic Research on Mathematics Education (JARME), 1 (1).

Pamuji, D.S. (2017). Kemampuan Membaca Cepat dengan Metode Skimming Siswa Kelas XI IPS SMA Negeri 3 Merlung Tahun Ajaran 2016/2017. PENA: Jurnal Pendidikan Bahasa dan Sastra, 7 (1), 70-83.

Pratama, R. A. (2016). Pengembangan Modul Membaca Kritis dengan Model Intruksi Langsung Berbasis Nilai Karakter. Dialektika: Jurnal Bahasa dan Sastra, dan Pendidikan Bahasa dan Sastra Indonesia, 3 (2), 17390.

Siregar, S. (2013). Statistik Parametrik. Jakarta: PT Bumi Aksara.

Subadiyono. (2017). Pengembangan Buku Teks Membaca Kritis. Jurnal Pendidikan Bahasa dan Sastra, 1 (6), 57-72.

Sugiyono. (2017). Statistik untuk Penelitian. Bandung: Alfabeta.

Tampubolon, Dp. (2015). Kemampuan Membaca Teknik Membaca Efektif dan Efisien (Rev.Ed). Bandung: Angkasa.

Tarigan, H.G. (2015). Membaca sebagai Suatu Keterampilan Berbahasa (Rev. Ed). Bandung: Angkasa Tari. 